УДК 330

\title{
МАНИПУЛИРОВАНИЕ ФИНАНСОВОЙ ОТЧЕТНОСТЬЮ: ПРИЗНАКИ И МЕТОДЫ ВЫЯВЛЕНИЯ
}

\author{
Татаровская Татьяна Евгеньевна \\ к.э.н., доцент, доцент \\ ФГАОУ ВО «Самарский государственный \\ экономический университет»
}

\begin{abstract}
Аннотация: В статье рассмотрены цели манипулирования финансовой отчетности, приведены сигналы опасности (признаки) искажения отчетных данных согласно классификации Ассоциации сертифицированных экспертов по мошенничеству. Автором предложено использование в качестве метода выявления манипуляции модели Бениша, представлены задачи комплаенсконтроля в области предотвращения манипулирования финансовой отчетностью.

Ключевые слова: финансовая отчетность, манипулирование финансовой отчетностью, корпоративное мошенничество, красные флажки, модель Бениша, комплаенс-контроль.
\end{abstract}

\section{MANIPULATION OF FINANCIAL STATEMENTS: SIGNS AND IDENTIFICATION METHODS}

\section{Tatarovskaya Tatyana Evgenyevna}

\begin{abstract}
The purposes of manipulating financial statements, danger signals (signs) of accounting data distortion according to the Association of Certified Fraud Experts classification are considered in the article. The author suggested the use of the Benish model as a method of detecting manipulation, revealed the tasks of compliance control in the field of preventing manipulation of financial statements.
\end{abstract}

Key words: financial reporting, manipulation of financial statements, corporate fraud, red flags, Benish model, compliance control.

Понятие «корпоративное мошенничество» не закреплено в современном российской законодательстве несмотря на многообразие его проявлений. 
Поэтому в вопросах определения ответственности при выявлении факта манипулирования данными, представленными в отчетности, необходимо руководствоваться нормами, предусмотренными уголовным и административным законодательством для преступлений в сфере мошенничества. В частности, статья 159 УК РФ «Мошенничество», статья 285 УК РФ «Злоупотребление должостными полномочиями» и т.п. охватывают широкий спектр преступлений, в которых наблюдаются признаки корпоративного мошенничества, а именно:

- форма осуществления: действие или бездействие (физического и/или юридического лица (лиц));

- наличие корыстного умысла;

- цель - получение личной выгоды и/или выгоды иного характера;

- нанесение ущерба юридическому лицу (данный признак отличает корпоративное мошенничество от обычного мошенничества);

- вид ущерба: материальный и/или нематериальный;

- способ совершения преступления: обман, злоупотребление доверием, введение в заблуждение или иным образом.

Результатом осуществления преступных деяний в виде корпоративного мошенничества является искажение финансовой отчетности экономического субъекта, представление недостоверной информации о финансовохозяйтсвенной деятельности юридического лица заинтересованным лицам, совершение коррупционных действий, нанесение ущерба активам предприятия $[1$, c. 580$]$.

Среди многообразия проявлений корпоративного мошенничества манипулирование финансовой отчетностью является одним из наиболее часто встречаемых проявлений. Помимо того, что мошеннические действия сами по себе приводят к искажению финансовой отчетности, манипулирование отчетными данными также может выступать самостоятельной целью для преступных лиц.

Причинами манипулирования финансовой отчетностью могут быть:

1) привлечение акционеров, инвесторов;

2) получение кредита, займа;

3) занижение налоговой базы для целей исчисления налога на добавленную стоимость, налога на прибыль, налога на имущество и других налогов; 
4) стремение получить бонусы и премии за выполнение целевых показателей или KPI (Key Performance Indicators);

5 ) сокрытие фактов хищения внутри экономического субъекта;

6) привест компанию к состоянию фиктивного банкротства и др.

Признаки манипулирования финансовой отчетностью в международной практике носят название «красный флажки» (red flags). Существуют расширенные списки «красных флажков», свидетельствующих прямо или косвенно о намеренном искажении данных финансовой отчетности. Кроме того, данные признаки возможно классифицировать с финансовой и нефинансовой позиции. В данной статье рассмотрим классификацию, разработанную Ассоциацией сертифицированных экспертов по мошенничеству (ACFE), которая называет данные признаки еще и «сигналами опасности». Приведем некоторые из них:

1. Завышение выручки следующими способами:

- отражение выручки без учета скидок, налогов, а также выручки от фиктивных продаж, которых в действительности не было;

- использование агентских договоров, договоров комиссии и иных посреднических договоров для сокрытия сумм расходов;

- нарушение принципов метода начисления: отражение будущих доходов в текущем отчетном периоде и др.

Сигналами опасности (красными флажками) в данном случае будут: увеличение выручки без роста поступлений денежных средств; сложные факты хозяйственной жизни и схемы осуществления расчетов с контрагентами; необоснованное увеличение оборачиваемости дебиторской задолженности и Т.П.

2. Занижение расходов следующими способами:

- отражение прямых расходов, формирующих себестоимость продаж, в составе прочих (внереализационных расходов);

- отражение процентных расходов по заемным источникам в составе активов, тем самым классифицируя кредитный договор, заключенный для покрытия текущих целей, как инвестиционный;

- сокрытие расходов, отражение их в других отчетных периодах.

Сигналами опасности (красными флажками) в данном случае будут: значительное увеличение прибыли, стоимости основных средств и нематериальных активов и др. 
3. Проведение некорректной оценки активов или обязательств следующими способами:

- завышение стоимости актива или занижение сумм обязательств, связанных с этим активом;

- манипулирование резервами, их некорректное использование;

- изменение сроков полезного использования;

- манипулирование при определении справедливой стоимости и др.

Сигналами опасности (красными флажками) в данном случае будут: представление отрицательного сальдо по операционной деятельности в отчете о движении денежных средств, хотя в отчете о финансовых результатах представлена диаметрально противоположная картина [2, с. 128]; использование субъективных суждений, сложных обоснований при определении стоимости актива и др.

4. Иные области манипулирования финансовой отчетностью:

- сокрытие или раскрытие некорректной информации об обязательствах, связанных сторонах;

- совершение необычных, сложных фактов финансовой жизни;

- использование фирм-однодневок, аффилированных, взаимосвязанных, взаимозависимых, подконтрольных юридических лиц для осуществления сделок;

- нарушение правил ведения бухгалтерского учета и др.

Сигналами опасности (красными флажками) в данном случае будут: отсутствие системы внутреннего контроля, большой объем необычных, сомнительных операций, корпоративные скандалы и др. [3]

Таким образом, именно указанные выше сигналы опасности («красные флажки») являются признаками манипулирования финансовой отчетностью. Они могут послужить основой для формирования методики выявления фактов манипулирования финансовой отчетностью.

В зарубежной практике одним из методов в этой сфере выступает модель М. Бениша, в результате использования которой определяется сводный индекс оценки риска фальсификации отчетности - M-score:

$$
\begin{aligned}
& \text { M-score }=-4,84+0,920 \cdot \mathrm{DSRI}+0,528 \cdot \mathrm{GMI}++0,404 \cdot \mathrm{AQI}+0,892 \cdot \mathrm{SGI} \\
& +0,115 \cdot \mathrm{DEPI}-0,172 \cdot \mathrm{SGAI}+4,679 \cdot \mathrm{TATA}-0,327 \cdot \mathrm{LVGI},
\end{aligned}
$$


где DSRI - индекс дневных продаж в дебиторской задолженности; GMI- индекс рентабельности продаж по валовой прибыли; AQI- индекс качества активов; SGI - индекс роста выручки; DEPI - индекс амортизации; SGAI - индекс коммерческих и управленческих расходов; LVGI- индекс коэффициента финансовой зависимости; ТАТА - индекс начисления к активам [4, c. 104].

Исследования Бениша показали, что значение сводного индекса M-score для организаций, манипулировавших прибылью, превышает минус 2,22.

С целью предотвращения совершения преступных деяний, которые повлекут за собой искажение финансовой отчетности рекомендуется внедрить систему комплаенс-контроля, задачами которой выступают оценка рисков корпоративного мошенничества и искажения финансовой отчетности, проведение внутрикорпоративных расследований совместно со службой безопасности, разработка мер профилактики.

\section{Список литературы}

1. Татаровская Т.Е. Риск-ориентированная система экономической безопасности предприятия // Экономика, предпринимательство и право. 2020. T. 10. № 3. С. 575-586.

2. Татаровская Т.Е., Татаровский Ю.А. Финансовая устойчивость и деловая активность в анализе экономической безопасности предприятия // Российский экономический интернет-журнал. 2019. № 4. С. 128.

3. Манипулирование финансовой отчетностью - схемы и способы выявления: Б. Сардарова. [Электронный ресурс]. 2013. URL: https://www.ippnou.ru/article.php?idarticle=011633 (дата обращения: 20.11.2021).

4. Романюк В.Б., Ерисов А.Ю. Современные подходы к выявлению рисков мошенничества и ошибок в финансовой отчетности компаний // Сибирская финансовая школа. 2019. № 5 (136). С. 102-107.

(C) Т.Е. Татаровская, 2021 